\title{
Intestinal pseudo-obstruction as a presenting symptom of Guillain-Barré syndrome
}

\author{
Bik Ling Man, Yat Pang Fu
}

Department of Medicine and Geriatrics, Tuen Mun Hospital, Hong Kong, Hong Kong

Correspondence to Dr Bik Ling Man, beli_man@yahoo.com

Accepted 14 June 2014
CrossMark

To cite: Man BL, Fu YP. BMJ Case Rep Published online: [please include Day Month Year] doi:10.1136/ bcr-2014-205155

\section{DESCRIPTION}

A 34-year-old man who had in the past enjoyed good health was admitted to the surgical department of our hospital for 1-week history of repeated vomiting and abdominal distension. He also had progressive limb weakness, paresthaesia of limbs and tachycardia for 2 days. Physical examination on admission revealed an alert but distressed patient. His blood pressure was $154 / 110 \mathrm{~mm} \mathrm{Hg}$, his pulse was $132 / \mathrm{min}$ and his body temperature was $36.4^{\circ} \mathrm{C}$. His abdomen was grossly distended and the bowel sound was absent. His upper limb power was medical research council (MRC) grade $5 / 5$ and his lower limb power was MRC grade 3/5. He had decreased pain and temperature sensation of the feet. There was generalised areflexia. ECG showed sinus tachycardia. Serum potassium was normal. Urgent CT abdomen revealed dilated duodenum, jejunum and proximal small bowels with multiple fluid levels (figure 1). Emergency laparotomy was performed revealing a grossly distended stomach and dilated small bowels. No definite pathology was identified. He was put on total parenteral feeding. He had acute retention of urine and labile blood pressure after admission. The patient had

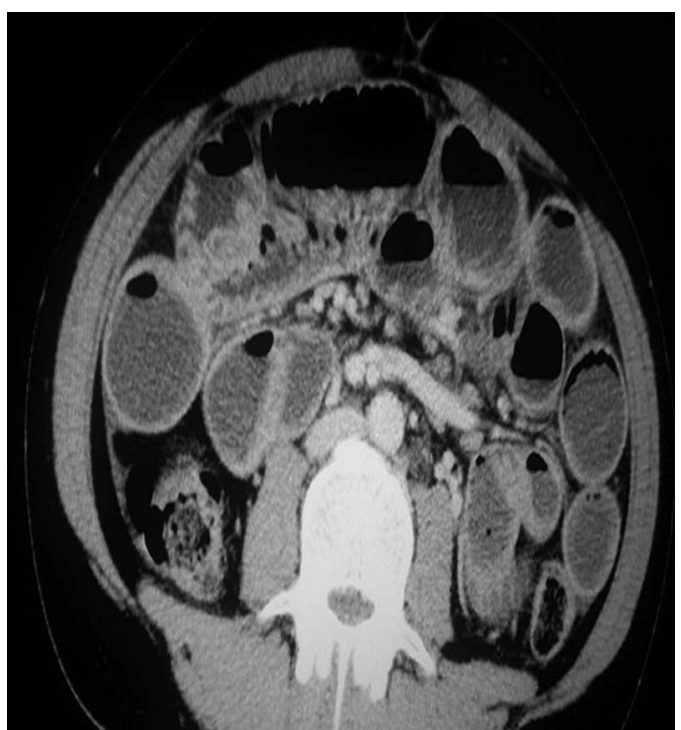

Figure $1 \mathrm{CT}$ abdomen with contrast showed dilated duodenum, jejunum, proximal small bowels with multiple fluid levels. persistent lower limb weakness and neurologists were consulted. A nerve conduction test on day 18 revealed demyelinating sensorimotor polyneuropathy. Cerebrospinal fluid examinations showed white cell count $<1 / \mathrm{cmm}^{3}(<5)$, protein $2.13 \mathrm{~g} / \mathrm{L}$ $(0.15-0.4)$ and glucose $3.6 \mathrm{mmol} / \mathrm{L} \quad(2.2-3.9)$. Serum anti-GD1b IgG was positive. Stool for campylobacter jejuni was negative. He was diagnosed to have Guillain-Barré syndrome (GBS) and was treated with a course of intravenous immunoglobulin. He did not need ventilator support. His ileus improved and he could resume oral feeding. His lower limb power improved to MRC grade $5 / 5$ and he was able to walk with a cane after 1 month.

Autonomic dysfunction is present in up to two-thirds of GBS patients. ${ }^{1}$ Paralytic ileus occurs in GBS due to the involvement of sympathetic and parasympathetic fibres. ${ }^{2}{ }^{3}$ Pseudo-obstruction is rarely reported as a presenting symptom of GBS. ${ }^{3}$ Accurate diagnosis may avoid unnecessary operation and treat the disease at an early stage.

\section{Learning points}

- Autonomic dysfunction is present in up to two-thirds of Guillain-Barré syndrome (GBS) patients.

- Paralytic ileus occurs in GBS due to involvement of sympathetic and parasympathetic fibres.

- Pseudo-obstruction is rarely reported as a presenting symptom of GBS.

Competing interests None.

Patient consent Obtained.

Provenance and peer review Not commissioned; externally pee reviewed.

\section{REFERENCES}

1 Lichtenfeld P. Autonomic dysfunction in the Guillain-Barre syndrome. Am J Med 1971;50:772-80.

2 Burns TM, Lawn ND, Low PA, et al. Adynamic ileus in severe Guillain-Barre syndrome. Muscle Nerve 2001;24:963-5.

3 Nowe T, Huttemann $\mathrm{K}$, Engelhorn $\mathrm{T}$, et al. Paralytic ileus as a presenting symptom of Guillain-Barre syndrome. J Neurol 2008:255:756-7. 


\section{Images in...}

Copyright 2014 BMJ Publishing Group. All rights reserved. For permission to reuse any of this content visit http://group.bmj.com/group/rights-licensing/permissions.

BMJ Case Report Fellows may re-use this article for personal use and teaching without any further permission.

Become a Fellow of BMJ Case Reports today and you can:

- Submit as many cases as you like

- Enjoy fast sympathetic peer review and rapid publication of accepted articles

- Access all the published articles

- Re-use any of the published material for personal use and teaching without further permission

For information on Institutional Fellowships contact consortiasales@bmjgroup.com

Visit casereports.bmj.com for more articles like this and to become a Fellow 